\title{
APPLYING AHP TO THE PROCESS OF DETERMINING THE BEST COMBINATION OF LOCATIONS TO A COMPANY'S MOBILE OPERATIONAL UNITS
}

\author{
Thiago Eichenberg \\ School of Management \\ Federal University of Rio Grande do Sul \\ Porto Alegre, RS, Brazil \\ E-mail: thiago.eichenberg@ fitolog.com.br \\ Denise Lindstrom Bandeira** \\ School of Management \\ Federal University of Rio Grande do Sul \\ Porto Alegre, RS, Brazil \\ E-mail: dlbandeira@ea.ufrgs.br \\ João Luiz Becker \\ School of Management \\ Federal University of Rio Grande do Sul \\ Porto Alegre, RS, Brazil \\ E-mail: jlbecker@ea.ufrgs.br
}

\begin{abstract}
This paper presents an application of the Analytic Hierarchic Process (AHP) technique in helping a decision-making process of a young and small sized company that developed and currently make use of a new mobile technology for the heat treatment of wooden packaging and pallets. The decision process comprised choosing the best combination of locations to place the company's three operational bases. As the heat treatment service must always be provided at the customers' premises, this decision is key to the company survival, as well as for its growth, as it influences a large number of important variables, such as operational costs, supply of skilled manpower, response time to costumer's requests, and others. The company's portfolio of clients is rising firmly because of the innovative technology used in the process of sterilization. It is currently formed by more than 30 customers spread within a 100,000 square miles area. For the young entrepreneur, thinking exclusively in terms of costs appeared to be a fallacy. That's why, in this case, the AHP was able to provide relevant inputs, by incorporating other factors beyond the purely financial view in its analysis. The factors involved, their hierarchical structure and relative weights, were generated in consensus by the company's managers and executives' opinion.
\end{abstract}

Keywords: heat treatment of pallets, group decision making, location problem, pest control

\footnotetext{
${ }^{*}$ Corresponding author

* The authors would like to thank CNPq and CAPES, two Brazilian governmental agencies, for supporting the research on which this work was based.
} 


\section{Introduction}

The location problem is one of the most important questions for many kinds of enterprises. Deciding where to locate a factory, a point of sale, or the operational base of a mobile unit, the case presented here, is a key decision. Both the choice of criteria and the evaluation of possible alternatives are critical steps in the decision-making process of choosing the best location. This paper presents an application of the Analytic Hierarchic Process (Saaty, 1980) technique to the process of selecting the best city to place the mobile operational units of Fitolog, a young and small Brazilian company in an accelerated process of growth.

The company in which the study was conducted, Fitolog Plague Control (Fitolog, 2010), is a two years old enterprise, which has been growing very quickly. Operating in the pest control market, over $90 \%$ of company sales comes from phytosanitary treatment of wooden pallets in international transit (export), in accordance with the international law ISPM 15. To carry out this type of service, Fitolog differentiates itself from its competitors by offering a unique heat treatment technology, fully developed by the company, called the Portable Chamber Process - Fitolog's PCP (Patent pending at INPI - Instituto Nacional da Propriedade Industrial - Brazil's National Institute of Intellectual Property).

Before the development of Fitolog's PCP, there were only two ways for the exporters to treat their wooden packaging and pallets:

- Methyl Bromide Fumigation (MBF): Chemical procedure performed by the application of the gaseous pesticide Methyl Bromide (MB) directly in the wooden pallets. After receiving an MB application, the packaging should be quarantined for 24 hours. The major disadvantage of this type of treatment is the environmental damage it causes, since MB reacts with ozone in the atmosphere. For this reason, this type of treatment is scheduled to be banned after 2015 (the use of MB in agriculture is already forbidden). $\mathrm{MBF}$ has a valuable logistical advantage, though, since it allows the process to be performed virtually at any site. The FMB equipment is quite small and can be assembled on light utility vehicles.

- Standard Heat Treatment (SHT): This type of treatment, besides being faster (average time ranging from two to three hours), is environment safe, since no pesticide is used. Only heat is used to eliminate pests. According to ISPM 15 an acceptable heat treatment must raise the core temperature of the wooden packaging up to $56{ }^{\circ} \mathrm{C}$, remaining at this temperature for at least 30 minutes. The major disadvantage of SHT is its immobility, heat treatment ovens generally being large structures, heavy and sturdy. Therefore, the client faces the transportation cost to move their wooden packaging to a heat treatment facility.

The technology developed by Fitolog, the Fitolog's PCP, sought to gather the advantages of both kinds of treatment in one. Besides being an environment friendly heat treatment, Fitolog's PCP is designed to be performed anywhere, replacing the heavy and static ovens, by portable chambers made with special thermal fabric, weighing about 65 pounds, connected to a compact heater module that can be shipped to the customer's site in light-trucks, giving full mobility to the process.

Combining high technology with low cost, Fitolog is able to offer its customers a cost-effective package of services. For this reason, in its two years of operation, the company has increased its market share very quickly, and in 2011 became the leading company in southern Brazil, in the segment of large exporters, its share rising up to $35 \%$. As a result the company's revenues four folded in the last year.

Because of its fast growth, the company's services reached over 50 large customers, spread within a 100,000 square miles area. Despite of this, its three mobile operational units still remain based at the company's headquarters in the city of Porto Alegre, state of Rio Grande do Sul, Brazil. This happened more or less by inertia, simply because the headquarters is located in Porto Alegre, and the company's 
executives started questioning this condition, thinking that it might be interesting to distribute the operational units in other sites. Five cities, including Porto Alegre, were pre-selected to locate mobile units in partnership with associates.

Following a deep literature survey (Fleury, Wanke, and Figueiredo, 2000; Moreira, 2008), seven criteria were identified as important for selecting the best location for the company's units. These criteria were clustered according to their relevance by a group of executives with the company, labeled (1) manpower, (2) administrative aspects (partnership and administrative control), (3) cost of inputs (LPG and diesel fuel (Fuel prices, 2010)) and (4) geography (proximity to technical support and proximity to consumer markets). Each city can perform differently in each criterion (or subcriterion) so the choice among alternatives was supported by the AHP as it made possible the cross-comparison of both qualitative and quantitative criteria.

\section{Development of the model}

The criteria used for modeling Fitolog's location selection problem are represented in Figure 1.

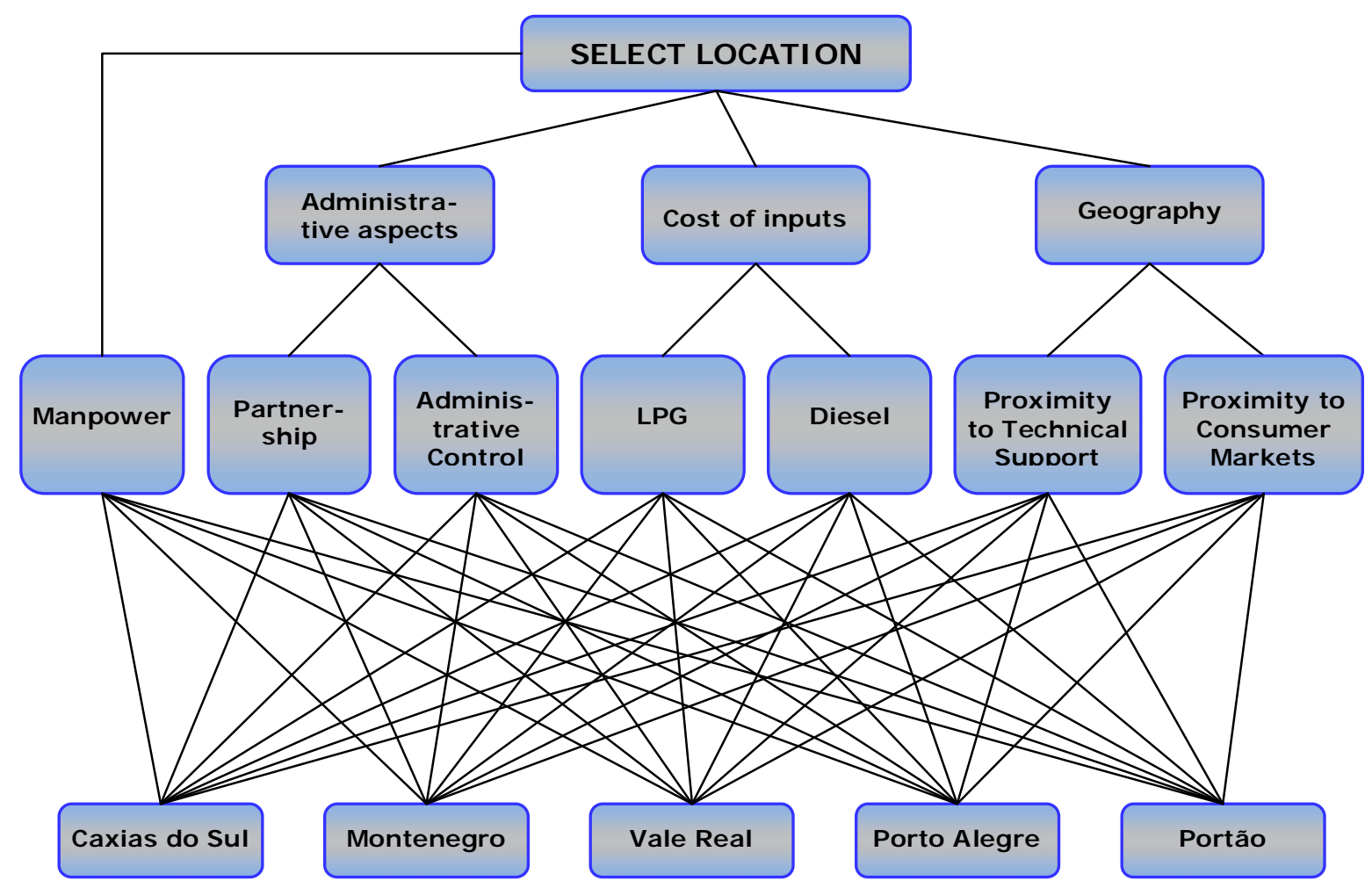

Figure 1. Hierarchical structure for the location selection problem.

The goal at the first level is defined by the question: which city should be chosen to house Fitolog's operational units? The criteria and subcriteria were validated in successive meetings with a group of three key executives of Fitolog, the company's CEO, the financial/administrative manager and the commercial manager. In the end, the criteria, subcriteria and the five pre-selected cities emerged from the consensus 
of all personnel involved in the study. Following the AHP technique, and using the hierarchical structure, all pairwise comparison between the objects from each hierarchical level in relation to each object in the hierarchical level immediately above were produced by the executives and incorporated into matrices depicting the scores. After analyzing the consistency ratios, the relative weights were distributed as shown in Table 1.

Table 1. Relative priority and CRs of the criteria and subcriteria.

\begin{tabular}{|l|l|c|c|}
\hline \multirow{2}{*}{ Criteria } & Subcriteria & $\begin{array}{c}\text { Relative } \\
\text { priority }\end{array}$ & CR \\
\hline \multirow{2}{*}{ Administrative aspects } & Partnership & 0.600 & 0.007 \\
\cline { 2 - 4 } & Administrative control & 0.400 & 0.006 \\
\hline \multirow{2}{*}{ Cost of inputs } & LPG & 0.400 & 0.000 \\
\cline { 2 - 4 } & Diesel & 0.600 & 0.000 \\
\hline \multirow{2}{*}{ Geography } & Proximity to technical support & 0.100 & 0.078 \\
\cline { 2 - 4 } & Proximity to consumer markets & 0.900 & 0.045 \\
\hline
\end{tabular}

The final ranking of the cities is presented in Table 2.

Table 2. Composite priorities of the alternatives.

\begin{tabular}{|c|c|c|c|c|c|}
\hline & $\begin{array}{c}\text { Manpower } \\
(\mathbf{0 , 0 7 1 )}\end{array}$ & $\begin{array}{c}\text { Administrative } \\
\text { aspects } \\
(\mathbf{0 . 2 1 4})\end{array}$ & $\begin{array}{c}\text { Cost of in- } \\
\text { puts } \\
(\mathbf{0 . 0 7 1})\end{array}$ & $\begin{array}{c}\text { Geography } \\
(\mathbf{0 , 6 4 3 )}\end{array}$ & Composite \\
\hline Caxias do Sul & 0.079 & 0.088 & 0.187 & 0.074 & $\mathbf{0 . 0 8 5}$ \\
\hline Montenegro & 0.092 & 0.092 & 0.187 & 0.218 & $\mathbf{0 . 1 8 0}$ \\
\hline Portão & 0.193 & 0.088 & 0.187 & 0.358 & $\mathbf{0 . 2 7 6}$ \\
\hline Porto Alegre & 0.455 & 0.492 & 0.253 & 0.220 & $\mathbf{0 . 2 9 7}$ \\
\hline Vale Real & 0.182 & 0.240 & 0.187 & 0.130 & $\mathbf{0 . 1 6 2}$ \\
\hline CR & $\mathbf{0 . 0 4 4}$ & $\mathbf{0 . 0 0 7}$ & $\mathbf{0 . 0 0 0}$ & $\mathbf{0 . 0 4 9}$ & $\mathbf{0 . 0 3 6}$ \\
\hline
\end{tabular}

\section{Analysis}

Even being defined by Moreira (2008) as a common, complex and often a crucial problem for many types of organizations, the location's selection of a new venture (or a relocation of an existing one) can be facilitated if the decision-maker has a well-structured model to compare the pre-selected location options. Allowing a mix of qualitative and quantitative aspects, the AHP appeared to be the best choice to solve Fitolog's location problem.

Before the use of AHP as a model to guide the decision process, the evaluation process was being done based purely on quantitative and financial aspects, such as cost of inputs and distance from the customers (farther customers mean higher traveling costs to the operational units). For this reason, the company's decision was being targeted to the choice of a more centralized city in the cluster of clients, such as 
Portão, Vale Real or Montenegro (see Figure 2) for the reduction of traveling costs, the variable with the greatest financial impact.

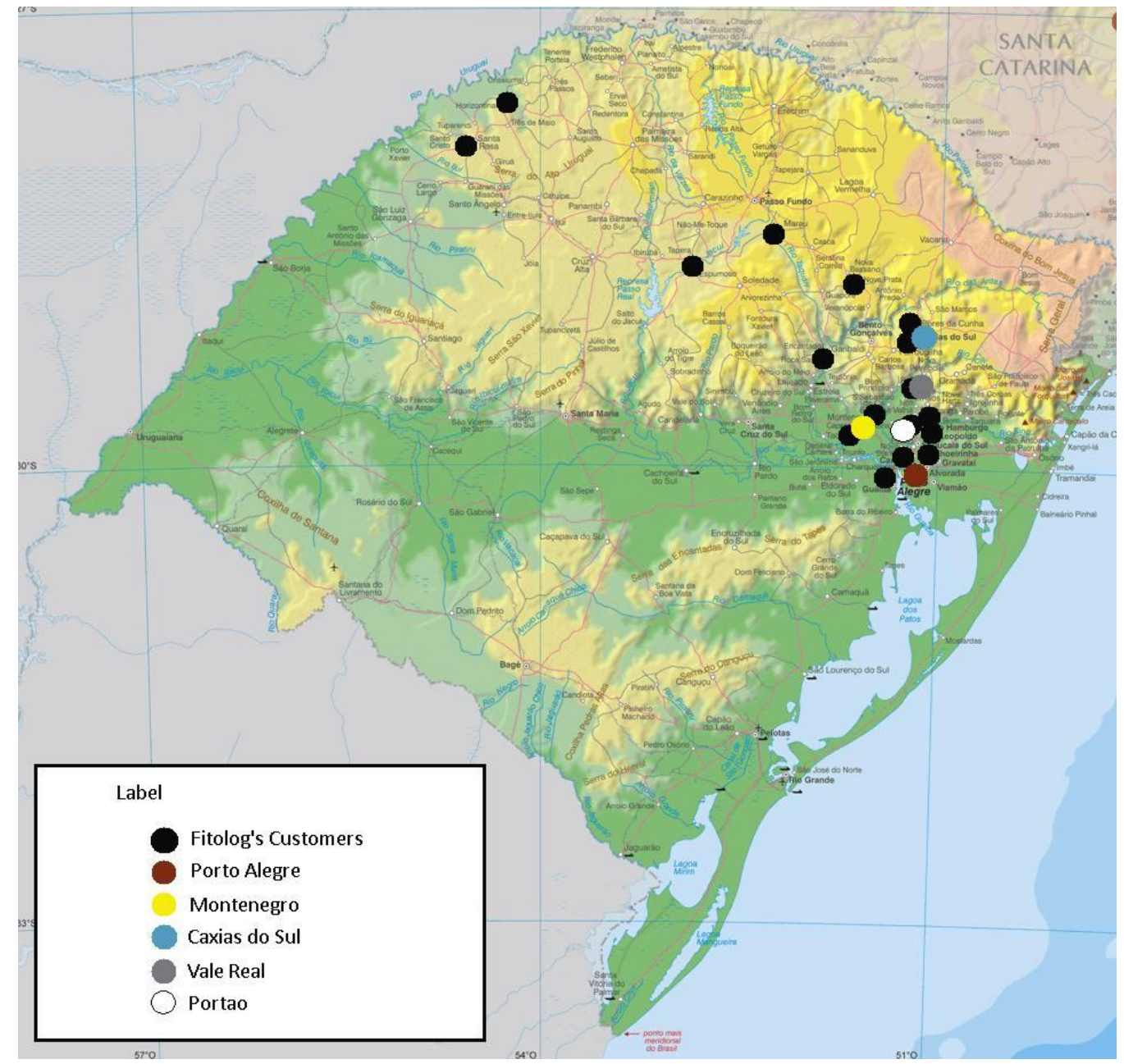

Figure 2. Fitolog's preselected cities and customers (IBGE, 2011)

The AHP based analysis, however, made it clear that this though was fallacious, since the technique indicated the city of Porto Alegre as the most interesting, in general, to serve as the operational base for Fitolog's mobile units. This happened because the city presented a series of qualitative benefits that were left out in strict financial assessments. Another interesting aspect of the use of AHP technique in solving Fitolog's problem of location was the ability to quantify the evaluation of qualitative aspects and the subsequent grouping of all criteria in a final number, creating an overall preference ranking of cities and many parallel rankings of criteria and sub criteria.

As Fitolog currently has three mobile operational units, it may choose to locate them all in the city with the highest overall score (Porto Alegre), or decentralize them in order to locate each one in different cities with complementary characteristics. For instance, it could be interesting to locate one unit in the nearest place to the consumer market (Portão), while the other two could be placed where the manpower and the administrative control are better (Porto Alegre). Therefore, the application of AHP as a model for evaluating alternative locations in Fitolog's case leaves the company's executives very well equipped with con- 
sistent data based on a multicriteria analysis that can safely guide the executives in any decision regarding defining the best combination of locations of the mobile operational units.

\section{REFERENCES}

Fitolog. (2010). Historic section. Retrieved from http://www.fitosystem.com.br/?p=empresa\&sp $=$ detalhes $\&$ id $=8$

Fitolog. (2010). Institutional section. Retrieved from http://www.fitosystem.com.br/?p=empresa\&sp= detalhes\&id=6

Fleury, P.F., Wanke, P., \& Figueiredo, K,F. (2000). Logística empresarial: A perspectiva brasileira. São Paulo: Atlas.

Fuel prices. (2010). Preço dos combustíveis - Brasil. Retrieved from http://www.precodoscombustiveis. com.br/mapa/busca

IBGE. (2011). Instituto Brasileiro de Geografia e Estatística. Retrieved from http://www.ibge.gov.br/ ibgeteen/mapas/

Moreira, D.A. (2008). Administração da produção e operações. São Paulo: Cengage Learning.

Saaty, T.L. (1980). The analytic hierarchy process: Planning, priority setting, resource allocation. New York: McGraw-Hill. 